\title{
Biodiversity of predominant Bacillus isolated from afitin, iru and sonru at different fermentation time
}

\author{
Paulin AZOKPOTA ${ }^{1 *}$, Peter L. MØLLER ${ }^{2}$, Joseph D. HOUNHOUIGAN ${ }^{1}$ and Mogens \\ JAKOBSEN $^{2}$ \\ ${ }^{1}$ Département de Nutrition et Sciences Alimentaires, Faculté des Sciences Agronomiques, Université \\ d'Abomey-Calavi, 01 BP 526, Cotonou, Bénin. \\ ${ }^{2}$ Department of Food Science and Food Microbiology, Royal Veterinary and Agricultural University, \\ Rolighedsvej 30, DR-1958 Frederiksberg C, Denmark. \\ *Corresponding author, Tel: (+ 229) 213601 22; Fax: (+229) 213601 22; E-mail: azokpotap@yahoo.fr
}

\begin{abstract}
Two hundred (200) presumptive isolates of Bacillus collected at different fermentation time from spontaneous fermented samples of afitin, iru and sonru produced in three different regions of Benin were identified at species and strains levels. ITS-PCR-RFLP revealed that $79 \%$ of the isolates were really identified as Bacillus, $5 \%$ as Staphylococcus and $16 \%$ as unidentified bacteria. The $16 \mathrm{~S}$ rDNA sequencing showed that $74.7 \%$ of the Bacillus belonged to the $B$. subtilis group and $25.3 \%$ to the B. cereus group. Additional biochemical tests and API 50 CHB system applied to 50 isolates randomly selected from the $B$. subtilis group divided the latter into $80 \%$ typical B. subtilis and 20\% typical B. licheniformis, which showed different PFGERFLP band patterns. Strains belonging to the $B$. cereus group were differentiated by PCR with specific primers BCW1F and BCW1R and specific enzymes EcoRI, Sau3AI and RsaI. All strains of the B. cereus group, except one, were found to be typical $B$. cereus. This work showed the predominance of $B$. subtilis in afitin, iru and sonru along the fermentation process.
\end{abstract}

(C) 2007 International Formulae Group. All rights reserved.

Keywords: Afitin, Iru, Sonru, Fermentation, Bacillus.

\section{INTRODUCTION}

Afitin, iru and sonru are three traditional condiments produced by spontaneous fermentation of African locust bean (Parkia biglobosa) in different regions of Benin. The condiments, mainly consumed in Benin as flavouring agents for sauces, soups and other dishes, are becoming increasingly popular, not only in poor families of villages but also in urban areas (Azokpota, 2005). Afitin is produced by spreading cooked locust bean cotyledons on basket trays and wrapping with several layers of jute to maintain a hot atmosphere for about $18 \mathrm{~h}$ (Azokpota et al., 2006). The jute are removed and the fermented mash is left to cool at ambient temperature for about $6 \mathrm{~h}$. Iru and sonru production involves the use of traditional additives and the fermentation lasts for about $48 \mathrm{~h}$ (Azokpota et al., 2006). Fermentation is known to be the crucial step during afitin, iru and sonru process (Gutierrez et al., 2000; Azokpota et al., 2006). The fermentation takes place naturally under uncontrollable conditions that often adversely affect the quality of the condiments generating misunderstandings and taboos among producers (Gutierrez et al., 2000).

Similar products like dawadawa (Nigeria), netetu (Senegal), soumbala (Burkina Faso), natto (Japan), thaï thua-nao (Thailand) have been fully studied (Odunfa, 1985; Antaï and Ibrahim, 1986; Diawara et al., 1992; N'Dir et al., 1994; Wang and Fung, 1996; Beaumont, 2002). Generally, for these products, the fermentation lasts between 3 and 
5 days and the microorganisms involved have been reported to be mainly $B$. subtilis, $B$. pumilus and $B$. licheniformis or $B$. subtilis variant natto (Allagheny et al., 1996; Beaumont, 2002; Ouoba et al., 2004). Furthermore B. cereus and Staphylococcus have also been found in traditional dawadawa and netetu as associate microorganisms (Odunfa and Oyewole, 1986; Odunfa, 1989; N'dir et al., 1994). Due to their role in the fermentation process and aroma production through their proteolytic and lipolytic activities, B. subtilis, B. subtilis variant natto, $B$. pumilus and $B$. licheniformis were reported to be good starter cultures to produce dawadawa, soumbala, natto, thaï thua-nao and others African locust or Soya bean-based condiments in controlled fermentation (Diawara et al. 1998; Beaumont, 2002; Ouoba et al., 2004).

In a preliminary study, Bacillus spp were found to be the dominant microorganisms in afitin, iru and sonru (Azokpota et al., 2006), suggesting that they could be targeted as possible starter cultures for the controlled fermentation of African locust bean to produce safe and reproducible quality of these condiments. It was reported that identification of microorganisms at species and strains level is a preliminary step for starter culture formulation (Ouoba et al., 2004). But to date, no detailed studies have been fully carried out to identify the Bacillus involved in afitin, iru and sonru at species or strains level. Actually, molecular genotyping techniques are considered to be effective and rapid tools for identification and characterization of Bacillus (O’Donnell et al., 1980; Marten et al., 2000; Miambi et al., 2003). These techniques include mainly restriction fragment length polymorphism of the PCR-amplified 16S-23S rDNA intergenic transcribed spacer (ITS-PCR-RFLP) for the grouping and typing of the isolates at species level (Jensen et al., 1993; Gütler and Stanisich, 1996; Joung and Coté, 2002), 16S rDNA sequencing for the description of phylogenetic relationships (Ash et al., 1992) and pulsed field gel electrophoresis (PFGE) for the differentiation of isolates at strain level (Liu and Chen, 1997; Mendo et al., 2000). In many cases, for better results, these biological molecular techniques are sometimes coupled with biochemical test and API systems
(Ouoba et al., 2004). The aim of this work was to identify, at species and strain level, the predominant Bacillus isolated from the spontaneous fermented samples of afitin, iru and sonru, using molecular genotyping techniques, coupled with biochemical tests and API 50 CHB systems. Identification of Bacillus at species and strain level in afitin, iru and sonru is the first step of starter culture formulation to be used for the process of these condiments in controlled fermentation.

\section{MATERIALS AND METHODS Preliminary identification}

Two hundred (200) isolates of Bacillus were collected from samples of afitin (50), iru (70) and sonru (80) produced at three different occasions by two local producers and isolated at different fermentation time, as reported by Azokpota et al. (2006). The bacteria were enumerated, first, on Dextrose Tryptone Agar (DTA, Oxoid, CM 75, Basingstoke, Hampshire, England), as described earlier (Azokpota et al., 2006), and then purified by successive subculturing on the same culture medium. Preliminary identification was based upon colony morphology and appearance, Gram staining of cell and catalase reaction (Harrigan and McCance, 1976; Guiraud and Galzy, 1980; Sneath, 1986). During the study, purified cultures were grown and put on DTA agar slant at $5^{\circ} \mathrm{C}$. The isolates were maintained at $-80^{\circ} \mathrm{C}$ in $800 \mu \mathrm{l}$ of Nutrient Broth (Difco 0003-17-8, Detroit, MI, USA) added to $400 \mu \mathrm{l}$ of sterile glycerol $80 \%$.

\section{Identification by ITS-PCR-RFLP, 16S rDNA sequencing and PFGE Identification using ITS-PCR-RFLP and the $16 S$ rDNA sequencing}

The Bacillus spp were grouped and identified at species level, using ITS-PCRRFLP, 16S rDNA sequencing, respectively, based upon genotyping as described by Ouoba et al. (2004).

\section{Pulsed Field Gel Electrophoresis (PFGE) analysis}

Identification at strain level was ensure using PFGE analysis according to the method of Ouoba et al. (2004) modified as followed: Cultures grown for $18 \mathrm{~h}$ in Nutrient Soya with shaking at $37{ }^{\circ} \mathrm{C}$ were used to prepare plugs cells; $600 \mu \mathrm{l}$ of culture were centrifuged at $14000 \mathrm{x}$ g for $2 \mathrm{~min}$. One thousand microliters $(1000 \mu \mathrm{l})$ of SE buffer were added to the 
pellet and centrifuged at $14000 \mathrm{x}$ g for $2 \mathrm{~min}$. Six hundred microliters $(600 \mu \mathrm{l})$ of SE buffer were added to the cells and $100 \mu \mathrm{l}$ of the cell suspension were diluted before the $\mathrm{OD}_{600}$ was measured. The remaining $500 \mu \mathrm{l}$ were centrifuged and the pellet was suspended in an amount in $\mathrm{ml}$ of SE buffer corresponding to $\mathrm{OD}_{600}$ and the suspension was dried at $90{ }^{\circ} \mathrm{C}$ for $5 \mathrm{~min}$. The Bacterial suspension $(90 \mu \mathrm{l})$ was mixed with $90 \mu \mathrm{l}$ of $2 \%$ Low-Melting agarose (Biolab, Richmond, Calif.) and cell pellets were digested with $500 \mu \mathrm{l}$ of Lysozym/mutanolysin dilution ((Lysozym/ mutanolysin buffer (50 mM EDTA pH 8.5, $0.05 \%$ N-laryl-sarcosin), $2 \mathrm{mg} / \mathrm{ml}$ of lysozym and $3 \mathrm{U} / \mathrm{ml}$ mutanolysin) at $37{ }^{\circ} \mathrm{C}$ for $18 \mathrm{~h}$. Formed plugs were also digested with $500 \mu \mathrm{l}$ proteinase K dilution at $53{ }^{\circ} \mathrm{C}$ for $18 \mathrm{~h}$. Plugs were washed with $1 \mathrm{ml}$ of $50 \mathrm{mM}$ EDTA with shaking and kept in $50 \mathrm{mM}$ EDTA at $5{ }^{\circ} \mathrm{C}$. A quarter $(1 / 4)$ of the plug was cut off and incubated for $30 \mathrm{~min}$ in $0.1 \mathrm{ml}$ of NE buffer 4 (10x). The buffer was removed and $0.1 \mathrm{ml}$ enzyme buffer added $(12 \mathrm{U} / 0.1 \mathrm{ml}$ ApaI) followed by incubation at $25{ }^{\circ} \mathrm{C}$ for $18 \mathrm{~h}$. Two hundred milliliters $(200 \mathrm{ml})$ of $1 \%$ agarose were boiled for $10 \mathrm{~min}$ in an autoclave (open valve) and cooled down to $50{ }^{\circ} \mathrm{C}$. The agarose was added to the mould. Two liters (2 l) of $0.5 \times$ TBE buffer were prepared and a few $\mathrm{ml}$ of $0.5 \times$ TBE buffer was added in the wells before loading the samples. The agarose gel was run with CHEF-DRII Drive module (Biorad, Bie and Bernstein A-S) at $14{ }^{\circ} \mathrm{C}$ for 17 hours, followed by staining in ethidium bromide for 1 hour and washing with demineralized water with shaking for 2 hours before the gel was photographed.

Product was successively digested with three restriction enzymes, EcoRI (R0101S, New England Biolabs), RsaI (R0177S, New England Biolabs) and Sau3AI (169S, New England Biolabs). In each case, gel electrophoresis was run as previously described, applying $7 \mu \mathrm{l}$ of each restricted DNA

\section{Differentiation of $B$. subtilis group}

Fifty (50) isolates randomly selected from the closely related $B$. subtilis group have been differentiated. Anaerobic growth of the isolates was tested by inoculating tryptic soya broth (Difco, 0370-17-3) supplemented with $1 \%(\mathrm{w} / \mathrm{v})$ glucose into tubes and incubating in a Gas Pack anaerobic system (BBL Gas Pack, MD 21152 USA) according to the manufacturer's instructions. Turbidity indicative of growth in the tubes was observed after 14 days at 37 and $55{ }^{\circ} \mathrm{C}$. Aerobic cultures were used as control and incubated in the same conditions, as described by O’Donnell et al. (1980). Nutrient agar (Remel, 454182, Bie and Berntsen, Rødovre, Denmark) in plate dishes was inoculated with each isolate and incubated at $55{ }^{\circ} \mathrm{C}$ for $48 \mathrm{~h}$ to control for maximum temperature growth. Plate dishes incubated at $37^{\circ} \mathrm{C}$ for $48 \mathrm{~h}$ were used as control. Propionate utilization was tested by inoculating slant tubes of nutrient agar containing sodium propionate (1 g), potassium chloride ( $1 \mathrm{~g})$, magnesium sulphate monohydrate (1.2 g), diammonium hydrogen phosphate $(0.5 \mathrm{~g})$, agar $(15 \mathrm{~g})$, solution of phenol red $0.04 \%(20 \mathrm{ml})$ and distilled water (1000 ml) with each isolate and incubating at 37 and $55{ }^{\circ} \mathrm{C}$ for 14 days. The analysis was followed by the fermentation of carbohydrates using API 50 CHB galleries according to the manufacturer's instructions.

\section{Differentiation of $B$. cereus group}

The method described by Manzano et al. (2003) and modified as follows was used to differentiate $B$. cereus group. The DNA template for PCR was the same as that used for the PCR analysis for the 16S-23S rDNA ITS-PCR-RFLP. Amplification took place in $50 \mu \mathrm{l}$ reaction mixture containing $5 \mu \mathrm{l}$ of PCR buffer (10 x), $5 \mu \mathrm{l}$ of $\mathrm{MgCl}_{2}(25 \mathrm{mM}), 1 \mu \mathrm{l}$ of forward primer BCFW1 (150 pmol/ $/ \mathrm{l})$ (5'GTT TCT GGT GGT TTA CAT GG -3'), $1 \mu \mathrm{l}$ of reverse primer BCRW1 (147 pmol/ $\mu)(5$ 'GGT GGA ATT AAA TCA TAC GTT G-3') (DNA Technology Ahrus, Denmark), $0.25 \mu \mathrm{l}$ of Taq-Polymerase (1.25UI) (Amersham Pharmacia Biotech, USA), $20.75 \mu$ l of autoclaved MilliQ water (Millipore) and $1 \mu \mathrm{l}$ of DNA template. Amplification conditions consisted of $95{ }^{\circ} \mathrm{C}$ denaturation for $5 \mathrm{~min}, 35$ cycles of $95^{\circ} \mathrm{C}$ for $1 \mathrm{~min}, 60^{\circ} \mathrm{C}$ for $1 \mathrm{~min}, 72$ ${ }^{\circ} \mathrm{C}$ for $1 \mathrm{~min}$ and a final extension at $72{ }^{\circ} \mathrm{C}$ for 7 min before cooling at $4{ }^{\circ} \mathrm{C}$ in a PCR thermocycler (Trio-Thermoblock, Biometra, Göttingen, Germany). The PCR product was successively digested with three restriction enzymes, EcoRI (R0101S, New England Biolabs), RsaI (R0177S, New England Biolabs) and Sau3AI (169S, New England 
Biolabs). In each case, gel electrophoresis was run as previously described, applying $7 \mu \mathrm{l}$ of each restricted DNA.

\section{RESULTS AND DISCUSSION}

At the genus level, phenotypic characterization of the isolates obtained from afitin, iru and sonru showed typical colony and cell morphology that identified isolates as belonging to the genus Bacillus, according to Harrigan and McCance (1976), Guiraud and Galzy (1980) and Sneath (1986). ITS-PCRRFLP fingerprinting of the isolates resulted in four representative groups (Fig.1). Bacillus of group I were homogeneous, showing the same type of three-band pattern, and represented $60.7 \%$ of the Bacillus isolates. They were found in all the three condiments. Those of group II showed two bands and represented $17.7 \%$ of the Bacillus isolates. They were found only in afitin and sonru. Those of group III showed four bands, the feature distinguishing them from those of group I being an additional major band of $400 \mathrm{bp}$. They represented about $14 \%$ of the Bacillus isolates and were found in all the three condiments. Those of group IV had only one band and represented $7.6 \%$ of the Bacillus isolates. They were found only in afitin and iru. Twenty percent $(20 \%)$ of the bacteria isolated from afitin (5\% of the total isolates) differed completely from those of the above four groups. They formed a fifth group and were characterized by 2 bands, one of 140 and the other of 1200 bp (results not shown). Sixteen percent (16\%) of the total isolates, all from iru and sonru, showed no PCR bands. Distribution by group and by condiment of the Bacillus identified by PCR-RFLP and 16S rDNA sequencing are shown in Table 1 .

Table 1 Main groups of Bacillus spp. identified in afitin, iru and sonru by PCR-RFLP and 16S rDNA sequencing

\begin{tabular}{|c|c|c|c|c|c|}
\hline \multirow{2}{*}{$\begin{array}{l}\text { PCR }^{1} \\
\text { groups }\end{array}$} & \multirow{2}{*}{$\begin{array}{c}\text { ITS-PCR }{ }^{2} \text { size } \\
\text { (bp) }\end{array}$} & \multirow{2}{*}{$\begin{array}{l}\text { 16S rDNA } \\
\text { sequencing }\end{array}$} & \multicolumn{3}{|c|}{ Distribution of $B$. subtilis group among the condiments (\%) } \\
\hline & & & Afitin & Iru & Sonru \\
\hline I & $140 ; 200 ; 340$ & B. subtilis group & 92 & 90.7 & 61.5 \\
\hline \multirow[t]{3}{*}{ III } & $140 ; 200 ; 340 ; 400$ & B. subtilis group & 8 & 9.3 & 38.5 \\
\hline & & & \multicolumn{3}{|c|}{ Distribution of B. cereus group among the condiments (\%) } \\
\hline & & & Afitin & Iru & Sonru \\
\hline II & $140 ; 200$ & B. cereus group & 60 & 0 & 100 \\
\hline IV & 250 & B. cereus group & 40 & 100 & 0 \\
\hline
\end{tabular}

${ }^{1}$ : Polymerase Chain Reaction ; ${ }^{2}$ : Intergenic Transcribed Spacer- Polymerase Chain Reaction; bp (base pair): International Standard Unit in Molecular biology; ${ }^{3:}$ International Standard abbreviation used in Molecular biology to design the position of a sequence gene related to a DNA (Desoxyribose Nucleic Acid).

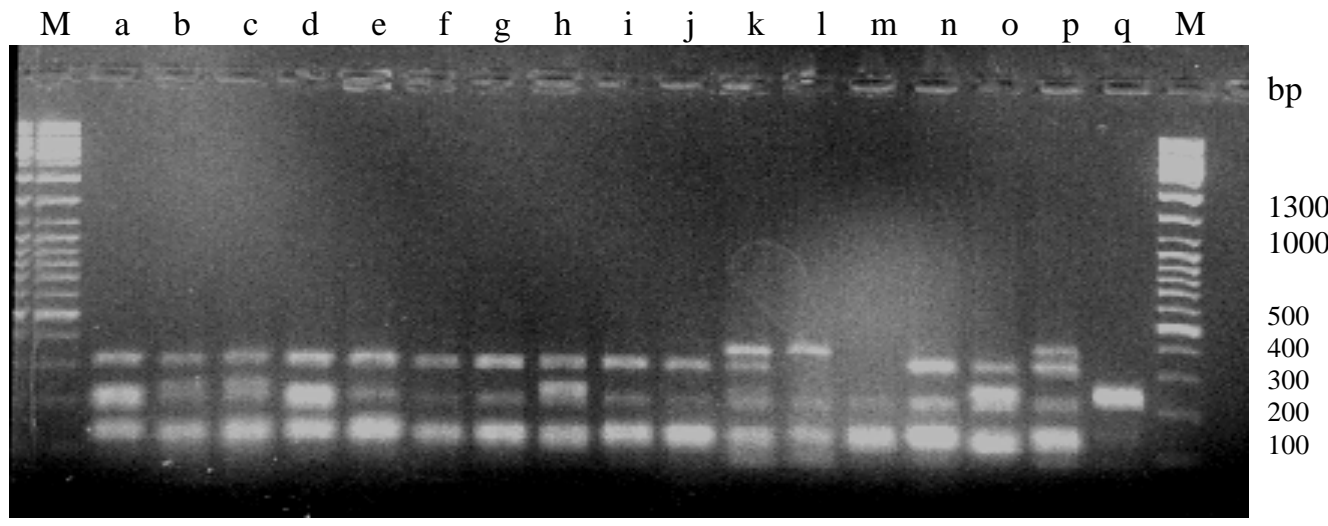

Fig. 1: ITS-PCR-RFLP electrophoretic profile of the main groups of the bacteria isolated from afitin, iru and sonru. The fragment size products were amplified with $16 \mathrm{~S}-1500 \mathrm{~F}$ and $23 \mathrm{~S}-32 \mathrm{R}$ primers on $2 \%$ agarose gel. Lanes a, b, c, d, e, f, g, h, i, j, n, o: group I (96 isolates); lane m: group II (28 isolates); lanes k, l, p: group III (22 isolates) and lane q: group IV (12 isolates). Lane M: DNA size marker (Gene Ruler ${ }^{\text {TM }}$ DNA Ladder mix SM 0332, MBI Fermentas). 
At the species level, the sequences of representative isolates from the four groups were aligned with those in the Genbank database. Groups I and III were identified as belonging to the closely related $B$. subtilis group, which comprises $B$. subtilis and $B$. licheniformis with percent identity varying from 97 to $99 \%$. They represent $74.7 \%$ of the total Bacillus isolated from the three condiments and $62.5 \%, 90 \%$ and $67.2 \%$ of those isolated from afitin, iru and sonru respectively.

The sequencing results agreed with the ITS-PCR-RFLP analysis: it has been seen that bacteria of groups I and III differentiated by ITS-PCR-RFLP were identified by 16S rDNA sequencing as belonging to the $B$. subtilis group which represents the dominant species in afitin, iru and sonru. The bacteria of groups II and IV were similarly identified by $16 \mathrm{~S}$ rDNA as belonging to the $B$. cereus group at species level.

It was not possible to distinguish $B$. subtilis from $B$. licheniformis or $B$. cereus from $B$. thuringiensis by $16 \mathrm{~S}$ rDNA sequencing. Both groups have been reported to be so closely related that they could not easily be distinguished by sequencing the $16 \mathrm{~S}$ rDNA (Rainey et al., 1994; White et al., 1993; Daffonchio et al., 1998).

Utilization of propionate by the strains as an organic substrate was illustrated by the production of red color in the tubes (Guiraud and Galzy, 1980; O’Donnell et al., 1980; Sneath, 1986). On this basis, a total of $80 \%$ (40/50) of the isolates randomly selected from the closely related B. subtilis group didn't growth neither at $55{ }^{\circ} \mathrm{C}$, nor in anaerobic conditions and didn't use propionic acid as substrate. Consequently, they were identified as typical $B$. subtilis (Table 2), whereas the remaining 20\% (10/50) which was grown at $55{ }^{\circ} \mathrm{C}$ in anaerobic conditions and used propionic acid as substrate was identified as typical B. licheniformis (Table 2). The biochemical properties of the 50 investigated Bacillus agreed with the descriptions of O'Donnel et al. (1980) and Odunfa and Oyewole (1986). In both cases, these results were identical to the results of the fermentation of carbohydrates by the investigated isolates using API 50 CHB systems (results not shown).
Similarly, fermented locust bean products such as dawadawa, soumbala and netetu are dominated by $B$. subtilis (Odunfa and Oyewole, 1986, Ouoba et al., 2004; N'dir et al., 1994). For an example of comparison, as for afitin, iru or sonru, the B. subtilis strains identified by the ITS-PCR-RFLP in soumbala were characterized by three bands (Ouoba et al., 2004). However, a difference was observed concerning the molecular sizes of band patterns of $B$. subtilis isolated in the two types of condiment. It is quite remarkable that the molecular size of band patterns of $B$. subtilis from soumbala were relatively higher than those of $B$. subtilis identified in afitin, iru or sonru (Ouoba et al., 2004) which means that the latter moved more quickly in the agarose gel than $B$. subtilis isolated from soumbala. This difference could confer to the strains specific characteristics to be investigated. Even more species including $B$. pumilus and $B$. sphaericus have been identified in soumbala (Ouoba et al., 2004).

At the strains level, the PFGE fingerprints of 20 Bacillus strains including 15 $B$. subtilis and five B. licheniformis are shown in Fig. 2. From this figure, the PFGE patterns were heterogeneous and some differences were observed between the isolates, although $B$. subtilis strains from afitin were identical, with the same band patterns around $25 \mathrm{kbp}$ (Fig. 2: lanes c, d, e and f). Among the other strains, some B. subtilis from iru (Fig. 2: lanes $\mathrm{g}$ and i) showed band patterns very similar to those from afitin, which have a molecular weight of about $50 \mathrm{kbp}$, while others (Fig. 2: lanes $m$ and $n$ ) showed very different ones. Two B. subtilis strains from sonru (Fig. 2: lanes $\mathrm{o}$ and $\mathrm{p}$ ) have the same profile but are totally different from those from afitin and $i r u$, as they have additional bands with a molecular size of about $194 \mathrm{kbp}$. Strains of $B$. licheniformis from both iru (lanes $\mathrm{h}$ and $\mathrm{j}$ ) and sonru (lanes $\mathrm{r}, \mathrm{s}$, and $\mathrm{t}$ ) showed similar band patterns. A little difference is in a $B$. licheniformis strain from sonru (lane $t$ ), the band intensity of which appears weak. Three strains of $B$. subtilis including two from afitin (Fig. 2: lanes a, b) and one from iru (lane k) didn't show clear band patterns by PFGE.

These results show the diversity among the isolates. It was possible to discriminate between $B$. subtilis strains from the same 
Table 2. Biochemical differentiation of 50 isolates randomly selected from the Bacillus subtilis group (B. subtilis and B. licheniformis)

\begin{tabular}{|c|c|c|c|c|c|}
\hline No. & Code strains & Growth at $37^{\circ} \mathrm{C}$ & Growth at $55^{\circ} \mathrm{C}$ & Anaerobic growth & $\begin{array}{l}\text { Utilization of } \\
\text { propionate }\end{array}$ \\
\hline \multicolumn{6}{|c|}{ B. subtilis $(80 \%)$} \\
\hline & Afitin & & & & \\
\hline 1 & F0H1 & + & - & - & - \\
\hline 2 & $\mathrm{~F} 0 \mathrm{H} 2$ & + & - & - & - \\
\hline 3 & FOH7 & + & - & - & - \\
\hline 4 & F6H4 & + & - & - & - \\
\hline 5 & F6H9 & + & - & - & - \\
\hline 6 & F6H10 & + & - & - & - \\
\hline 7 & F12H7 & + & - & - & - \\
\hline 8 & F12H8 & + & - & - & - \\
\hline 9 & F12H9 & + & - & - & - \\
\hline 10 & F18H5 & + & - & - & - \\
\hline 11 & F18H6 & + & - & - & - \\
\hline 12 & F18H10 & + & - & - & - \\
\hline 13 & F24H3 & + & - & - & - \\
\hline 14 & F24H9 & + & - & - & - \\
\hline 15 & $\begin{array}{l}\text { F24H10 } \\
\text { Iru }\end{array}$ & + & - & - & - \\
\hline 16 & Y0H2 & + & - & - & - \\
\hline 17 & Y0H3 & + & - & - & - \\
\hline 18 & Y6H2 & + & - & - & - \\
\hline 19 & Y6H4 & + & - & - & - \\
\hline 20 & Y12H1 & + & - & - & - \\
\hline 21 & $\mathrm{Y} 12 \mathrm{H} 2$ & + & - & - & - \\
\hline 22 & Y12H4 & + & - & - & - \\
\hline 23 & Y18H4 & + & - & - & - \\
\hline 24 & Y18H5 & + & - & - & - \\
\hline 25 & Y18H6 & + & - & - & - \\
\hline 26 & Y18H10 & + & - & - & - \\
\hline 27 & Y24H5 & + & - & - & - \\
\hline 28 & Y24H9 & + & - & - & - \\
\hline \multirow[t]{2}{*}{29} & Y24H10 & + & - & - & - \\
\hline & Sonru & & & & \\
\hline 30 & $\mathrm{BaOH} 5$ & + & - & - & - \\
\hline 31 & $\mathrm{Ba} 0 \mathrm{H} 10$ & + & - & - & - \\
\hline 32 & Вa0H11 & + & - & - & - \\
\hline 33 & Ba12H14 & + & - & - & - \\
\hline 34 & Ba12H15 & + & - & - & - \\
\hline 35 & Ba12H16 & + & - & - & - \\
\hline 36 & Ba18H12 & + & - & - & - \\
\hline 37 & Ba18H13 & + & - & - & - \\
\hline 38 & Ba18H14 & + & - & - & - \\
\hline 39 & Ba18H16 & + & - & - & - \\
\hline 40 & Ba24H5 & + & - & - & - \\
\hline \multicolumn{6}{|c|}{ B. licheniformis (20\%) } \\
\hline & iru & & & & \\
\hline 1 & Y36H4 & + & + & + & + \\
\hline 2 & Y36H5 & + & + & + & + \\
\hline 3 & Y36H9 & + & + & + & + \\
\hline 4 & Y36H10 & + & + & + & + \\
\hline 5 & Y48H5 & + & + & + & + \\
\hline 6 & $\begin{array}{l}\text { Y48H9 } \\
\text { sonru }\end{array}$ & + & + & + & + \\
\hline 7 & Ва24H9 & + & + & + & + \\
\hline 8 & Ва24H10 & + & + & + & + \\
\hline 9 & Ва24H14 & + & + & + & + \\
\hline 10 & Ba48H5 & + & + & + & + \\
\hline
\end{tabular}




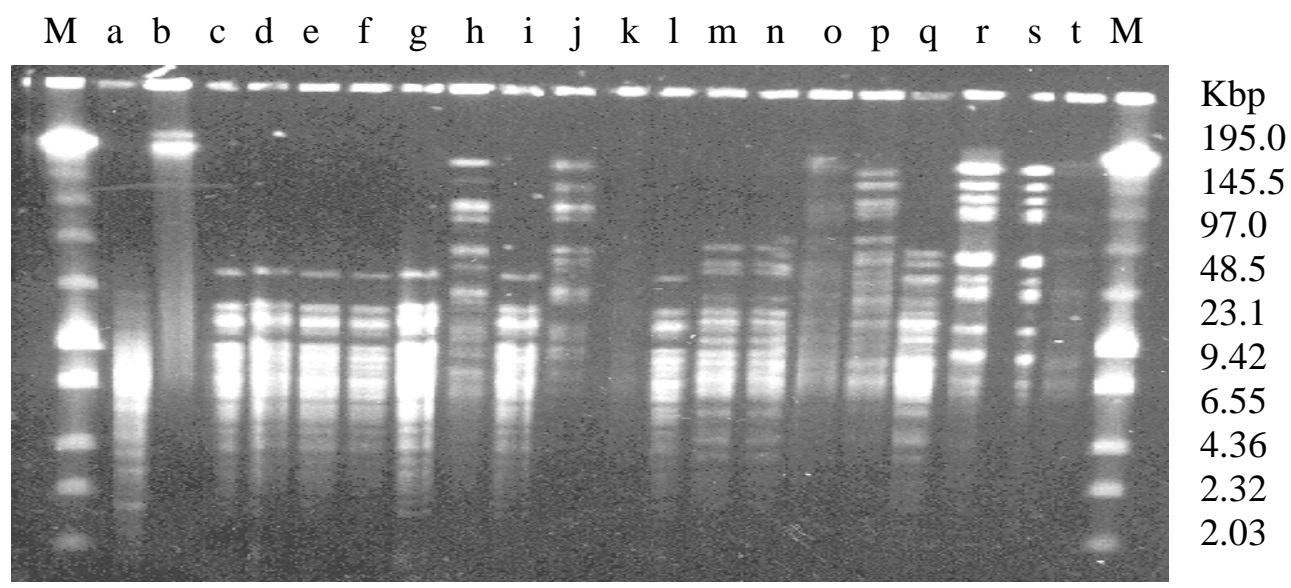

Fig. 2: Pulse-Field Gel Electrophoretic profile of B. subtilis group on 2 \% Low-Melting agarose (Biolab, Richmond, Calif.). Lane M :DNA size marker (Low Range PFG marker 350S, new England, Biolabs); lanes c, d, e, f, g, i, l: B1; lanes h, j and p: B2; lanes m and n: B3; lanes r and s: B4 ; Lanes a, b, k: B5 ; lane o: B6; lane q: B7 lane $\mathrm{t}: \mathrm{B} 8$.

condiment as well as from different condiments. In addition some $B$. subtilis strains isolated from afitin and sonru had the same patterns. A clear difference was also observed between B. licheniformis strains identified in iru and in sonru (Fig. 2). Furthermore, the fact that $B$. licheniformis was found only in iru and sonru at the latter stage of the fermentation (between 24 and $48 \mathrm{~h}$ could be partially explained by the length or by the nature of the fermentation. It was reported that afitin process involved a short fermentation (24 h), whereas the fermentation of African locust beans to produce iru and sonru occurred over $48 \mathrm{~h}$. In addition, iru and sonru process involves the use of traditional additive called yanyanku by local producers, contrary to afitin (Azokpota et al., 2006).

Bacillus of groups II and IV belong to the $B$. cereus group and comprise $B$. cereus and $B$. thuringiensis at a similarity of 98 or $99 \%$. They represent $25.3 \%$ of the total Bacillus and $37.5 \%, 10 \%$ and $32.7 \%$ of those isolated from afitin, iru and sonru, respectively. The PCR products of the 40 isolates of the $B$. cereus group digested with EcoRI, Sau3AI and RsaI endonucleases were 350, 200 and 300 bp, respectively (Fig. 3). The digested PCR fragment size corresponds in each case to that of $B$. cereus, when compared to data from the literature (Manzano et al., 2003).On this basis all the isolates of the $B$. cereus group, except one, were identified as typical $B$. cereus.
Generally, B. cereus strains were also found in many African fermented locust bean condiments (Ouoba et al., 2004) and were reported to be potentially enterotoxic (Granum et al., 1996; Choma and Granum, 2002). However, to date, no foodborne diseases have been reported in Benin due to the consumption of afitin, iru or sonru. Overall, clinical investigations are needed to confirm whether some $B$. cereus strains identified in afitin, iru and sonru are toxigenic and whether they represent a potential hazard for consumers.

The details results of identification by PCR-ITS-RFLP of the presumptive Bacillus spp isolated from the three condiments at different fermentation time are shown in Fig. 4. A total of $33.3 \%$ of $B$. cereus strains in afitin were found during the first $6 \mathrm{~h}$ of fermentation (Fig. 4a). Three of the six $B$. cereus strains identified in iru were isolated at the start of fermentation (Fig. 4b). In contrast, no $B$. cereus was found in sonru during the same period of fermentation (Fig. 4c), suggesting that the process environment which varies from one condiment to another, might influence the growth and distribution of B. cereus during fermentation process. Furthermore, $16 \%$ of the isolates obtained from iru and sonru could not be identified (Fig. 4: $b$ and c) because of the absence of PCR bands, a phenomenon that we were unable to explain. The large number of $B$. subtilis strains isolated from afitin, iru and 


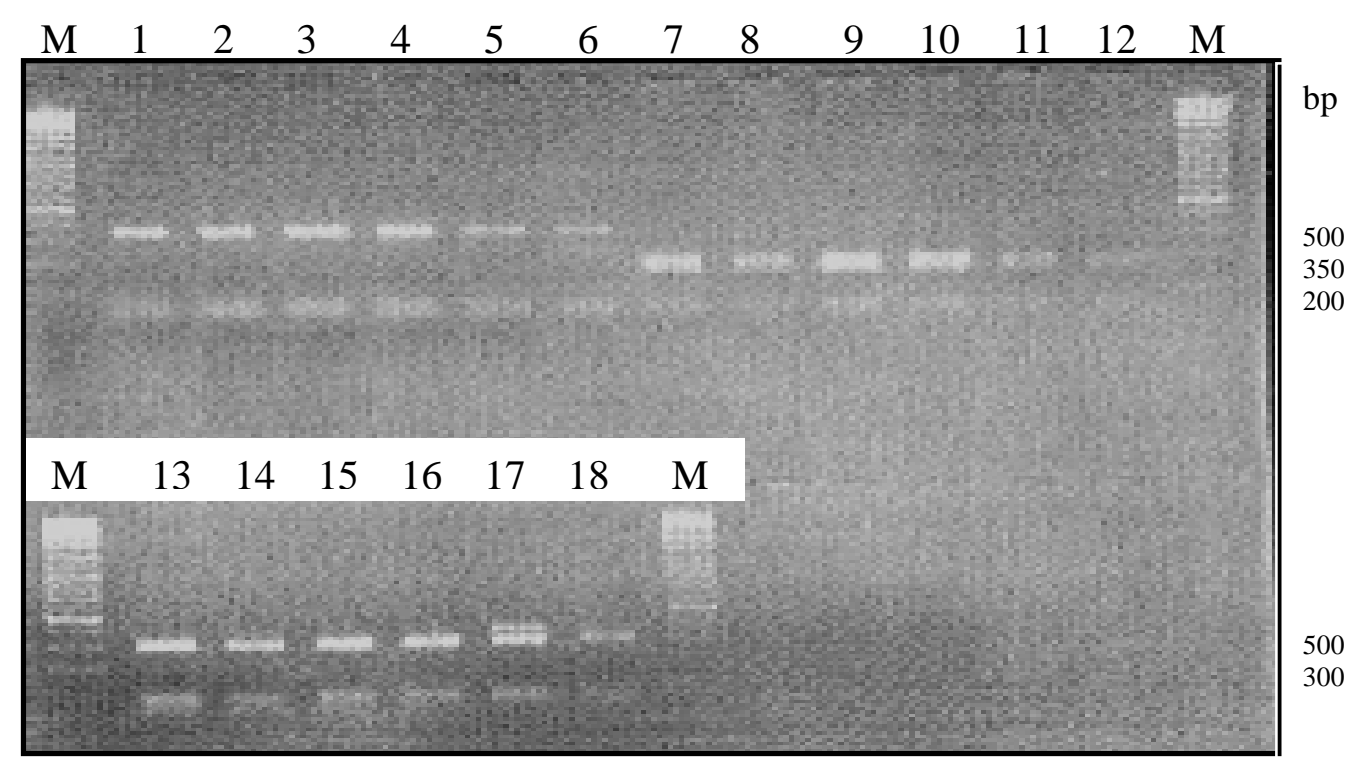

Fig. 3: PCR-RFLP of B. cereus group. Digestion was done with EcoR1 (lanes 1-6); Sau3A1 (lanes 7-12) and Rsa1 (lanes 13-18). MWM: molecular weight marker 100 bp (Sigma, Aldrich).

sonru (74.7\% of the total Bacillus spp.) and the fact that they were broadly distributed among the three condiments according to the fermentation time demonstrate their abundance and diversity in the three products.

Five percent $(5 \%)$ of the total isolates were identified as belonging to the Staphylococcus aureus group with percent identity of $94 \%$. They were found only in afitin. They correspond to bacteria with ITSPCR-RFLP fingerprints with two bands, one of 140 and the other of $1200 \mathrm{bp}$.

Globally, except for the minor group of Staphylococcus, the isolates from afitin, iru and sonru were identified as belonging to the genus Bacillus. The present findings can be generalized to any of alkaline fermentation of African locust or Soya bean using similar afitin, iru and sonru process. Several authors reported that Bacillus spp were generally the dominant microorganisms involved in the fermentation of African locust or Soya bean to produce different African or Asian traditional condiments as dawadawa, soumbala, netetu, natto or kinema (Odunfa and Oyewole, 1986; Aderibigbe and Odunfa, 1990; Diawara and al., 1992; Diawara and al., 1998; Kiers et al., 2000; Beaumont., 2002). The presence of the Staphylococcus in afitin may be opportunistic and these strains can be found in any of the three condiments, as demonstrated recent investigations which have revealed their presence also in iru and sonru. However, the presence of Staphylococcus in a fermented African locust bean product is not surprising, as Staphylococcus species have frequently been found in netetu (N'dir et al., 1994) and dawadawa (Odunfa, 1989; Omafuvbe et al., 2000). In addition, Bacillus pumilus which are absent in afitin, iru and sonru have been identified in soumbala. But, the particularity of the present study on afitin, iru and sonru resides in the investigation of a high number of Bacillus spp occurring in the three condiments according to the fermentation processes. For each process, Bacillus spp have been isolated at different fermentation time leading to a variety of isolates with potential specific characteristics to be used as starter culture. Physico-chemical characterization of Bacillus spp isolated from afitin, iru and sonru was then necessary in the perspective to get new information to be compared to the well-known characteristics of Bacillus spp identified in soumbala, dawadawa, netetu or kinema and for starter culture formulation to be used for afitin, iru and sonru process. 
a) Afitin

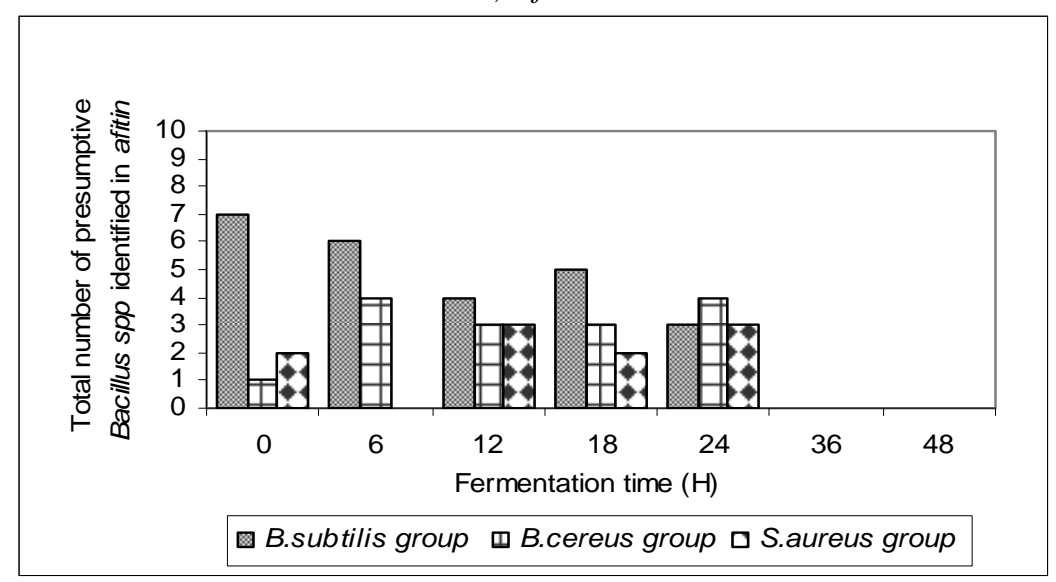

b) Iru

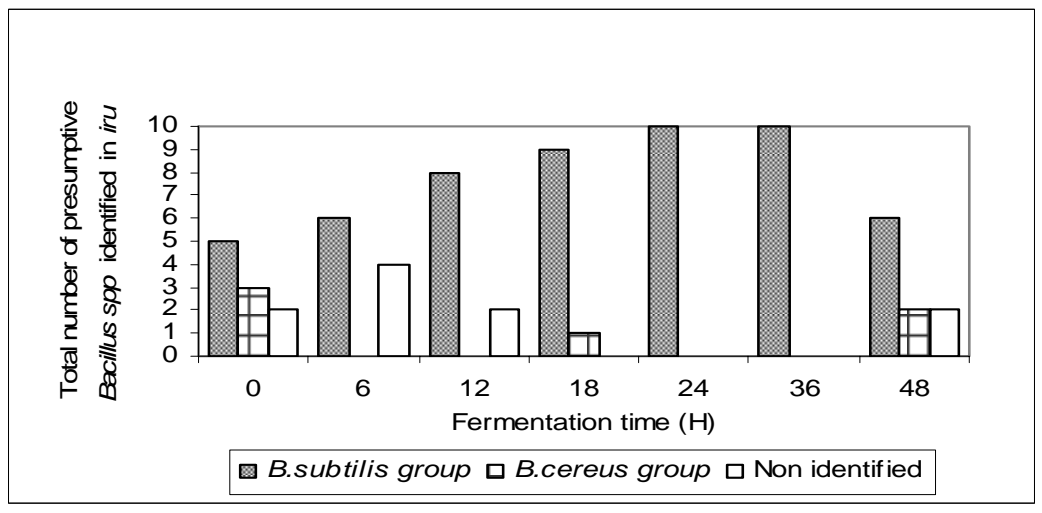

c) Sonru

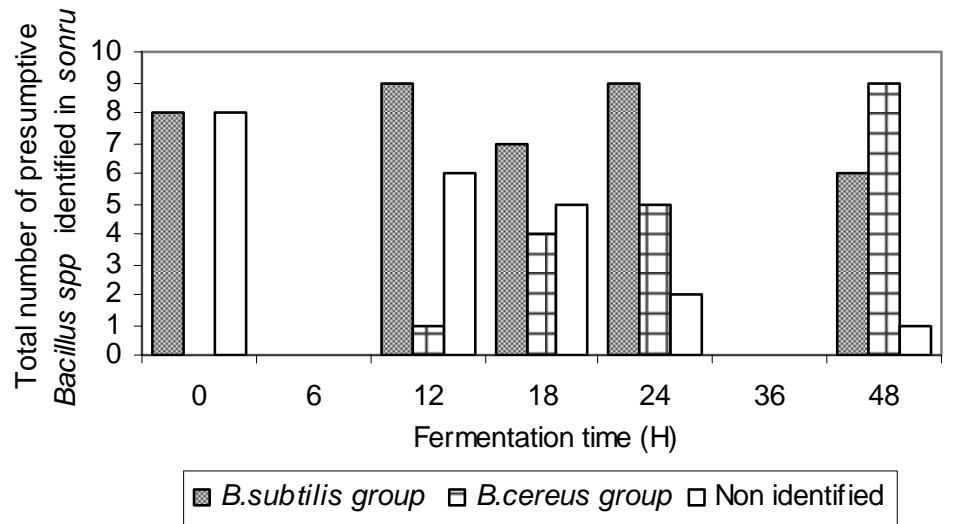

Fig. 4: Distribution of the number of bacteria identified in afitin, iru and sonru by PCR-ITSRFLP at different fermentation time. 


\section{Conclusion}

The identification of the predominant microorganisms in the fermented afitin, iru and sonru was performed in the present work for the first time. Diversity was observed at species level of Bacillus (primarily in $B$. subtilis but also in $B$. licheniformis and $B$. cereus) as well as at strain level. Staphylococcus spp were initially identified in afitin, but recent investigations have revealed their presence also in iru and sonru. B. subtilis and $B$. licheniformis were differentiated by $16 S$ rDNA sequencing and by additional biochemical testing and API 50 CHB system, illustrating the possibility of combining genotyping and phenotypic analyses to distinguish closely related $B$. subtilis and $B$. licheniformis species.

For further investigation, the identified Bacillus spp are potential target to be used as starters culture to produce afitin, iru and sonru in controlled fermentation. First of all, there is a need to deeply characterize these strains, since the final selection of strains to be used as starter culture will depend on individual performance under practical conditions, proteolytic or lipolytic activity and production of a desirable aroma.

\section{ACKNOWLEDGEMENTS}

This study was funded by the Danish International Development Assistance, Danish Foreign Ministry (DANIDA) through the "Capability Building for Research in Traditional Fermented Food Processing in West Africa” (ENRECA) project and by AireDéveloppement agency. A part of the study was undertaken at KVL in the laboratory of the Department of Food Microbiology of the Royal Veterinary and Agricultural University of Copenhagen in Denmark. The authors gratefully acknowledge the staff of this laboratory for scientific and technical support and Garth Evans for assistance with the English.

\section{REFERENCES}

Aderibigbe EY, Odunfa SA. 1990. Growth and extracellular enzyme production by strains of Bacillus species isolated from fermenting locust beans, iru. Journal of Applied Bacteriology, 69: 662-671.

Allagheny N, Obanu ZA, Campbell-Platt G, Owens JD. 1996. Control of ammonia during Bacillus subtilis fermentation of legumes. International Journal of Food Microbiology, 29: 321-333.

Antaï SP, Ibrahim MH. 1986. Microorganisms associated with African locust bean (Parkia biglobosa. Filicoida Welw) fermentation for "dawadawa” production. Journal of Applied Bacteriology, 61: 145148.

Ash C, Farrow JAE, Wallbanks S, Collins MD. 1992. Phylogenetic heterogeneity of the genus Bacillus revealed by comparative analysis of small-subunit ribosomal RNA sequences. Letters of Applied Microbiology, 13: 202-206.

Azokpota P. 2005. Etude de la dynamique physico-chimique et microbiologique de la fermentation des graines de néré pour la production de l'afitin, de l'iru et du sonru. Ph.D. Thesis. Université d'Abomey-Calavi- Université Royale Agricole et Vétérinaire de Copenhague au Danemark, $172 \mathrm{p}$.

Azokpota P, Hounhouigan DJ, Nago MC. 2006. Microbiological and chemical changes during the fermentation of African locust bean (Parkia biglobosa) to produce afitin, iru and sonru, three traditional condiments produced in Benin. International Journal of Food Microbiology, 107: 304-309.

Beaumont M. 2002. Flavoring composition prepared by fermentation with Bacillus spp. International Journal of Food Microbiology, 75: 189-196.

Choma C, Granum PE. 2002. The enterotoxin $\mathrm{T}$ (BcET) from Bacillus cereus can probably contribute to food poisoning. FEMS Microbiology Letters, 217: 115-119.

Daffonchio D, Borin S, Frova G, Gallo R, Mori E, Fani R, Sorlini C. 1998. 16S23S rDNA internal transcribed spacers as molecular markers for the species of the 16-rRNA group I of the genus Bacillus, FEMS Microbiology Letters, 163: 229236.

Diawara B, Sawadogo L, Kabore IZ. 1992. Contribution à l'étude des procédés traditionnels de fabrication du soumbala au Burkina Faso. Aspects biochimiques, microbiologiques et technologiques. Sciences et Techniques, 20: 5-14 
Diawara B, Sawadogo L, Amoa-Awua WKA, Jakobsen M. 1998. Quality system for the production of soumbala. The HACCP System. Taastrup: Waitro.

Granum PE, Andersson A, Gayther C, Giffel M, Larsen H, Lund T, O’Sullivan K. 1996. Evidence for a further enterotoxin complex produced by Bacillus cereus. FEMS Microbiology Letters, 217: 115119.

Guiraud J, Galzy P. 1980. L'analyse microbiologique dans les industries alimentaires (edn De l'Usine Nouvelle). Collection Génie Alimentaire: Paris; 8991

Gutierrez ML, Maizi P, Nago CM, Hounhouigan J. 2000. Production et commercialisation de l'afitin dans la region d'Abomey-Bohicon au Bénin. CERNA, CNEARC, CIRAD Librairie de CIRAD; 124p.

Gütler V, Stanisich A. 1996. New approaches to typing and identification of bacteria using the 16S -23S rDNA spacer region. Microbiology, 142: 3-16.

Harrigan WF, McCance ME. 1976. Laboratory methods in Foods and Dairy Microbiology. Acad. Press: London; 389p.

Jensen MA, Webster JA, Straus N. 1993. Rapid identification of bacteria on the basis of polymerase reaction-amplified ribosomal DNA polymorphism. Applied and Environmental Microbiology, 59: 945-952.

Joung KB, Coté JC. 2002. Evaluations of ribosomal RNA gene restriction patterns for the classification of Bacillus species and related genera. Journal of Applied Microbiology, 92: 97-108.

Kiers JL, Van laeken AEA, Rombouts FM. 2000. In vitro digestibility of Bacillus fermented Soya beans. International Journal of Food Microbiology, 60: 163169.

Liu PY-F, Chen S-L. 1997. Use of PulseFields Gel Electrophoresis to investigate a pseudo-Outbreak of $B$. cereus in a Pediatric Unit. Journal of Clinical Microbiology, 35: 1533-1535.

Manzano M, Cocolin L, Cantoni C, Comi G. 2003. Bacillus cereus, Bacillus thuringiensis and Bacillus mycoides differentiation using a PCR-RE technique. International Journal of Food Microbiology, 81: 249-254.

Marten P, Smalla K, Berg G. 2000. Genotypic and phenotypic differentiation of an antifungal biocontrol strain belonging to Bacillus subtilis. Journal of Applied Microbiology, 89: 463-471.

Mendo ALV, Henriques SI, Correia CMA, Duarte MCJ. 2000. Genetic Characterization of a New Thermotolerant Bacillus licheniformis Strain. Current Microbiology, 40: 137139.

Miambi E, Guyot J-P, Ampe F. 2003. Identification, isolation and quantification of representative bacteria from fermented cassava dough using an integrate approach of culture-dependent and culture-independent methods. International Journal of Food Microbiology, 82: 111-120

N'Dir B, Hbid C, Cornélius C, Roblain D, Jacques P, Vanhentenryck F, Diop M, Thonart P. 1994. Propriétés antifongiques de la microflore sporulée du nététu. Cahiers Agricultures , 3: 23-30.

Odunfa SA. 1985. Biochemical changes in fermenting African locust beans (Parkia biglobosa) during “iru” fermentation. Journal of Food Technology, 20: 295303.

Odunfa SA. 1989. Nutritional characteristics of Staphylococcus sp. From fermenting African locust bean (Parkia biglobosa). Die Nahrung Microbiology, 5: 195-200.

Odunfa SA, Oyewole BO. 1986. Identification of Bacillus species from "iru, a fermented African locust bean (Parkia biglobosa) product. Journal Basic Microbiology, 26: 101-108.

O’Donnell AG, Norris, JR, Berkeley, RCW, Clauss D, Kaneko T, Logan NA, Nozaki, R. 1980. Characterization of Bacillus subtilis, Bacillus pumilis, Bacillus licheniformis and Bacillus amyloliquefaciens by Pyrolysis GasLiquid Chromatography, Deoxyribonucleic Acid-Deoxyribonucleic Acid Hybridisation, Biochemical Tests and API Systems. International Journal of Systematic Bacteriology, 30: 448-459.

Omafuvbe BO, Shonukan OO, Abiose SH. 2000. Microbiological and biochemical changes in the traditional fermentation of 
soybean for 'soy-daddawa' Nigeria food condiment. Food Microbiology, 17: 469474

Ouoba LI, Diawara B, Amoa-Awua WK, Traoré AS, Moller PL. 2004. Genotyping of starter cultures of $B$. subtilis and $B$. pumilus for fermentation of African locust bean (Parkia biglobosa) to produce Soumbala. International Journal of Food Microbiology, 90(2): 197-205.

Rainey FA, Fritze D, Stackebrandt E. 1994. The phylogenetic diversity of thermophilic members of the genus Bacillus as revealed by $16 \mathrm{~S}$ rDNA analysis. FEMS Microbiology Letters, 115: 205-212.
Sneath PHA. 1986. Endospore-forming GramPositive Rods and Cocci. In Bergey's Manual of Systematic Bacteriology (2), Mair NS, Sharpe ME, Holt JG (eds). Waverly Press, Inc.; 1104 -1137.

Wang J, Fung DYC. 1996. AlkalineFermented Foods: A review with Emphasis on Pidan Fermentation. Critical Reviews in Microbiology, 22(2): 101-138.

White D, Sharp RJ, Priest FG. 1993. A polyphasic taxonomic study of thermophilic bacilli from a wide geographical area. Antonie Van Leeuwenhoek; International Journal of General Molecular Microbiology, 64: 357-386. 